42

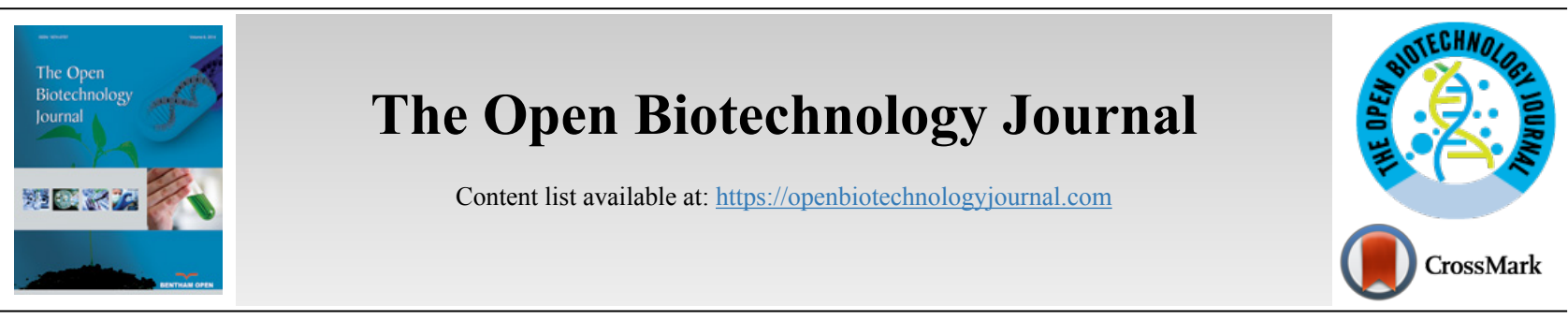

RESEARCH ARTICLE

\title{
A Comparative Proteomic Study of Thermobifida Cellulosilytica TB100 Secretome Grown on Carboxymethylcellulose and Rice Straw
}

\author{
Mai H. Elmahdy ${ }^{1, *}$, Ahmed F. Azmy ${ }^{1}$, Eman El-Gebaly ${ }^{1,2}$, Amal Saafan ${ }^{3}$ and Yasser Gaber ${ }^{1,4}$ \\ ${ }^{1}$ Department of Microbiology and Immunology, Faculty of Pharmacy, Beni-Suef University, 62511, Beni-Suef, Egypt \\ ${ }^{2}$ Department of Microbiology and Immunology, Faculty of Pharmacy, October 6 University, 12585, Cairo, Egypt \\ ${ }^{3}$ Department of Pharmaceutical Microbiology, Faculty of Pharmacy, Menoufia University, Shebeen El-kom, 51132, Egypt \\ ${ }^{4}$ Department of Pharmaceutics and Pharmaceutical Technology, Faculty of Pharmacy, Mutah University, 61710, Mutah, Jordan
}

\begin{abstract}
:
Background:

Cellulose, the major component of the plant cell wall, is the most abundant and cheap polymer on earth. It can be used by varieties of cellulolytic enzymes. Cellulases can hydrolyze cellulose to its glucose monomers, which can be fermented to many biotechnological products, such as biochemicals, bioplastics, and biofuels. Actinomycetes are potential sources of cellulases.

Objective:

The current study sheds light on the cellulolytic activity of Thermobifida cellulosilytica, a previously isolated thermophilic actinomycete, and the analysis of the lignocellulases produced in the secretome as a result of induction by different carbon sources.

Methods:

The cellulolytic activity was qualitatively confirmed by Congo red method showing a large halo zone around the colonies. The activity was also assayed using the 3,5-dinitrosalicylic acid (DNS) method. The secretome analysis was conducted by liquid chromatography-tandem mass spectroscopy (LC-MS/MS) based proteomic approach.

Results:

The cellulolytic activity increased by two folds upon the growth of T. cellulosilytica on rice straw (RS) as a complex substrate comparatively to Carboxymethylcellulose (CMC) as a simple one. These results were highly assured by LC-MS/MS. Where more proteins ( $\mathrm{n}=31$ ) were produced in the RS secretome, CMC produced only six proteins, including only one cellulase. Different classes of proteins produced in the RS secretome were cellulases $(26 \%)$, hemicellulases $(16 \%)$, proteases $(10 \%)$, and others $(48 \%)$.

Conclusion:

Lignocellulases are inducible enzymes. RS as a complex substrate induced $T$. cellulosilytica for the expression of more lignocellulolytic enzymes than $\mathrm{CMC}$.
\end{abstract}

Keywords: Carboxymethylcellulose, Carboxymethylcellulase, Thermobifida cellulosilytica, Rice straw , Secretome analysis , LC-MS/MS .

\begin{tabular}{|l|l|l|r|}
\hline Article History & Received: November 26, 2019 & Revised: January 22, 2020 & Accepted: February 27, 2020
\end{tabular}

\section{INTRODUCTION}

The lignocellulosic materials, left behind agricultural and forestry industries, are mainly composed of cellulose $40-50 \%$,

\footnotetext{
* Address correspondence to this author at the Department of Microbiology and Immunology, Faculty of Pharmacy, Beni-Suef University, 62511, Beni-Suef, Egypt; Tel: +201096656500; Fax: +20 822162136 ; E-mail: mai.elmahdy@pharm.bsu.edu.eg
}

hemicellulose $20-40 \%$, and lignin $20-30 \%$ of plant dry weight [1]. Their production was estimated by $1.5 \times 10^{12}$ tons per year [2]. Cellulose is a linear polymer ranging from 10,000-15,000 glucose units linked by $\beta-1,4$ glycosidic bonds [3] and may reach up to 25,000 glucose units [4]. Due to its highly ordered crystalline structure, water insolubility as well as the presence of a tough lignin layer around it, cellulose is slowly/hardly degraded and unusable, leading to its disposition and 
accumulation as waste in nature [5]. This may lead to environmental pollution [6]. So, intervention to accelerate cellulose degradation and conversion to its fermentable sugars that can be used for biorefinery and industrial purposes is a must.

The efficient hydrolysis of cellulosic waste materials, has been employed either chemically or enzymatically [4, 7]. Chemical hydrolysis methods of cellulose degradation include incineration (the routine method), pyrolysis, steam explosion, and acidic or alkaline treatment [8]. Nowadays, application of these chemical methods has been dramatically limited and restricted only to be a preliminary/pretreatment step before enzymatic hydrolysis [9] due to their many disadvantages including environmental pollution, health problems, requirement of large equipment, and production of toxic chemicals or inhibitors as furfural or even undesirable non-sugar by-product $[4,5,7]$.

On the other hand, the enzymatic degradation of cellulose can overcome all these drawbacks being clean, highly specific, and eco-friendly [7, 10]. The bioconversion of cellulosic wastes into its simple sugars has been employed by different hydrolytic and oxidative enzymes such as cellulases, hemicellulases (xylanases), lytic polysaccharide monooxygenases (LPMO) and peroxidases [1,11]. Cellulases are a group of three enzymes; endoglucanases or CMCase (carboxymethylcellulases) (E.C. 3.2.1.4), exoglucanases or CBHs (cellobiohydrolases) (E.C. 3.2.1.91) and $\beta$-glucosidases (BGLs) or cellobiases (E.C. 3.2.1.21), acting synergistically for complete hydrolysis of cellulose [4]. Microbial lignocellulolytic enzymes are mainly produced from bacteria, fungi, and actinomycetes, the most effective secretors of lignocelluloses [12].

Thermobifida cellulosilytica $\mathrm{TB} 100^{\mathrm{T}}$ strain is an actinomycete that has been isolated from manure compost region [13]. This strain showed $97.4 \%$ similarity to Thermobifida fusca, one of the well-characterized cellulolytic actinomycetes [13]. T. cellulosilytica becomes the subject of many recent researches due to its production of many important industrial enzymes such as cutinases and lignocellulases. Cutinases are efficiently used in plastic biodegradation, especially hydrolysis of PET (polyethylene terephthalate) [14]. Lignocellulases composed of cellulases, hemicellulases, and ligases are responsible for effective hydrolysis of lignocellulosic substrates [15].

Previous studies are focused on the identification of culture conditions, phenotypic, genotypic and taxonomic data of $T$. cellulosilytica TB100 ${ }^{\mathrm{T}}$ [ 13 ]. Little studies assessed the cellulolytic activity of this thermophilic strain [ 16 ]. Our research aimed to evaluate the cellulolytic potential of $T$. cellulosilytica grown on different carbon sources. This is the first work concerned with studying the effect of substrate type on the expression of different cellulases in the secretome collected from $T$. cellulosilytica using LC-MS/MS based proteomic analysis. This study can help the researchers interested in the production of thermophilic cellulases for industrial use.

\section{MATERIALS AND METHODS}

\subsection{Bacteria and Culture Conditions}

Thermobifida cellulosilytica $\mathrm{TB}_{100^{\mathrm{T}}}$ (DSM 44535) used in the present study was ordered from DSMZ (Deutsche Sammlung von Mikroorganismen und Zellkulturen), Germany. The lyophilized strain was aseptically resuspended in $1 \mathrm{ml}$ of Czapek peptone broth containing: sucrose $30 \mathrm{~g} / \mathrm{L}, \mathrm{NaNO}_{3} 3$ $\mathrm{g} / \mathrm{L}, \mathrm{K}_{2} \mathrm{HPO}_{4} 1 \mathrm{~g} / \mathrm{L}, \mathrm{MgSO}_{4} .7 \mathrm{H}_{2} \mathrm{O} 0.5 \mathrm{~g} / \mathrm{L}, \mathrm{KCl} 0.5 \mathrm{~g} / \mathrm{L}$, $\mathrm{FeSO}_{4} \cdot 7 \mathrm{H}_{2} \mathrm{O} 0.01 \mathrm{~g} / \mathrm{L}$, yeast extract $2 \mathrm{~g} / \mathrm{L}$, peptone $5 \mathrm{~g} / \mathrm{L}$ and water to $1 \mathrm{~L}$. PH was adjusted to 7.3. A volume of $100 \mu \mathrm{L}$ was added to $5 \mathrm{~mL}$ Czapek peptone broth for refreshment and was incubated at $45^{\circ} \mathrm{C}$ for 3-5 days. A glycerol stock was prepared and preserved at $-80^{\circ} \mathrm{C}$.

\subsection{Qualitative Detection of The Cellulolytic Activity of T. cellulosilytica}

The selected strain was cultivated on $\mathrm{CMC}$ agar media containing: CMC $0.5 \mathrm{~g} / \mathrm{L}, \mathrm{NaNO}_{3} 0.1 \mathrm{~g} / \mathrm{L}, \mathrm{K}_{2} \mathrm{HPO}_{4} 0.1 \mathrm{~g} / \mathrm{L}$, $\mathrm{MgSO}_{4} 0.05 \mathrm{~g} / \mathrm{L}$, yeast extract $0.05 \mathrm{~g} / \mathrm{L}$, agar $20 \mathrm{~g} / \mathrm{L}$ and water to $1 \mathrm{~L}$ by spot inoculation method. The plates were incubated at $50^{\circ} \mathrm{C}$ for $72 \mathrm{~h}$ then flooded with $0.1 \%$ Congo red dye, gently shaken for $20 \mathrm{~min}$, and excess dye was poured off. Finally, the plates were washed with $1 \mathrm{M} \mathrm{NaCl}$, gently shaken for $15 \mathrm{~min}$ and excess $\mathrm{NaCl}$ was poured off. The formation of a clear halo zone around the colony, that can be visualized as a purple color when flooded with $1 \mathrm{M} \mathrm{HCl}$ is considered as a positive result [17].

\subsection{Effect of Different Substrates on Cellulase Production}

Cellulase production was determined using CMC and RS, individually, as simple and complex substrate in the production medium containing the following constituents: CMC $5 \mathrm{~g} / \mathrm{L}$ or pre-treated RS $1 \%(\mathrm{w} / \mathrm{v}), \mathrm{MgSO}_{4} \cdot 7 \mathrm{H}_{2} \mathrm{O} 0.2 \mathrm{~g} / \mathrm{L}, \mathrm{KNO}_{3} 0.75$ $\mathrm{g} / \mathrm{L}, \mathrm{K}_{2} \mathrm{HPO}_{4} 0.5 \mathrm{~g} / \mathrm{L}, \mathrm{FeSO}_{4} .7 \mathrm{H}_{2} \mathrm{O} 0.02 \mathrm{~g} / \mathrm{L}, \mathrm{CaCl}_{2} 0.04 \mathrm{~g} / \mathrm{L}$, yeast extract $2 \mathrm{~g} / \mathrm{L}$ and water to $1 \mathrm{~L}, \mathrm{pH}$ was adjusted to 7.5. The RS was thermally and chemically pre-treated by $\mathrm{NaOH}$. RS treatment was done as described by Taniguchi [18] as following: RS was cut into small pieces, washed with tap water for removal of surface dust, and soaked in $2.5 \% \mathrm{NaOH}$ for $1 \mathrm{~h}$ with a proportion of 1:10 (w/v). The mixture was autoclaved at $121^{\circ} \mathrm{C}$ for $30 \mathrm{~min}$ and then filtered. The residue was washed with distilled water several times till the supernatant $\mathrm{pH}$ became neutral. Finally, the residue was filtered again and dried in the oven at $80^{\circ} \mathrm{C}$ for $10 \mathrm{~min}$. The microorganism was added to the flasks containing the previous production media with the corresponding substrates. The flasks were incubated at $50^{\circ} \mathrm{C}$, shaken at $150 \mathrm{rpm}$ for 11 days. A sample of one $\mathrm{mL}$ was periodically withdrawn every $24 \mathrm{~h}$ interval for assay of cellulase activity of $T$. cellulosilytica.

\subsection{Cellulase Assay}

After the specified incubation time, one milliliter of the production medium was withdrawn and centrifuged at $7000 \mathrm{xg}$ for $10 \mathrm{~min}$. Two hundred and fifty microliters of CFE (Cell Free Extract) was added to a reaction mixture composed of: $500 \mu \mathrm{L}$ of $\mathrm{CMC}$ and $250 \mu \mathrm{L}$ of $50 \mathrm{mM}$ phosphate buffer, $\mathrm{pH}$ was adjusted to 7 . The reaction mixture was incubated at $50^{\circ} \mathrm{C}$ for $2 \mathrm{~h}$, and the resulted reducing sugars were quantified by the DNS method [19] using a microtiter plate reader (Tecan Sunrise, Switzerland). A standard curve was constructed based on at least six different glucose concentrations to estimate the 
reducing sugars released. One international unit of enzymatic activity was defined as the amount of enzyme that released 1 $\mu \mathrm{mol}$ of reducing sugar per min.

\subsection{Partial Characterization of Crude Extract Produced from $T$. cellulosilytica}

The CFE resulted from $T$. cellulosilytica growing on CMC as sole carbon source was used for characterization as following:

\subsubsection{Optimum PH}

Different buffer systems with different $\mathrm{pH}$ were prepared. One hundred mM Citrate buffer with $\mathrm{pH} 4.5,5$ and 5.5 and 100 $\mathrm{mM}$ phosphate buffer with $\mathrm{pH} 6,6.5,7,7.5,8$ and 8.5 were used. The reaction mix was made with each prepared buffer and incubated at $50^{\circ} \mathrm{C}$ for $2 \mathrm{~h}$. The enzyme activity was assayed by the DNS method.

\subsubsection{Optimum Temperature}

Five hundred microliters of CMC $0.5 \%, 250 \mu \mathrm{L}$ buffer $\mathrm{pH}$ 8 and $250 \mu \mathrm{L}$ supernatant were mixed in Eppendorf tubes. The tubes were incubated at different temperatures $(4,25,30,37$, 50 , and $70^{\circ} \mathrm{C}$ ) for $2 \mathrm{~h}$. The enzyme activity was assayed by the DNS method.

\subsubsection{Optimum Substrate Concentration}

A typical reaction was prepared as following: in Eppendorf tubes, $500 \mu \mathrm{L}$ of different concentrations of CMC $(0.1 \%$, $0.25 \%, 0.5 \%, 0.75 \%$, and $1 \%$ ), $250 \mu \mathrm{L}$ buffer $\mathrm{pH} 8$ and $250 \mu \mathrm{L}$ supernatant were mixed. The tubes were then incubated at $50^{\circ} \mathrm{C}$ for $2 \mathrm{~h}$. A negative control tube containing distilled water instead of supernatant was incubated under the same conditions. The reducing sugar content was measured using the DNS method.

\subsection{Secretome Analysis of T. cellulosilytica Grown on Different Cellulose Substrates}

\subsubsection{Strain Cultivation and Secretomic Protein Extraction}

T. cellulosilytica $\mathrm{TB} 100^{\mathrm{T}}$ strain was cultivated on the production medium containing the corresponding substrates ( $0.5 \% \mathrm{CMC}$ and $1 \% \mathrm{RS}$, separately). The flasks were incubated at $50^{\circ} \mathrm{C}$ with shaking at $150 \mathrm{rpm}$ for 7 days. The secretome from each substrate was harvested by centrifugation at $7000 \mathrm{xg}$ at $4^{\circ} \mathrm{C}$ for $15 \mathrm{~min}$ twice to remove the bacterial pellets completely. The supernatant was concentrated and diafiltered through Vivaspin dialysis membrane with $5 \mathrm{kDa}$ MWCO (GE Healthcare Life Sciences, Uppsala, Sweden) with $10 \mathrm{mM} \mathrm{PO}_{4}^{-3}$ buffer $\mathrm{pH} \mathrm{7,} \mathrm{to} \mathrm{one-tenth} \mathrm{its} \mathrm{starting} \mathrm{volume.} \mathrm{The} \mathrm{protein}$ concentration of each sample was determined using the bicinchoninic acid assay method (BCA). The resultant volume aliquots were preserved at $-80^{\circ} \mathrm{C}$.

\subsubsection{Protein Digestion and LC-MS/MS Analysis}

The secretory proteins from each sample were chemically denaturated by $8 \mathrm{M}$ urea, reduced with $200 \mathrm{mM}$ DTT (dithiothreitol) for $30 \mathrm{~min}$ at room temperature, alkylated with
$1 \mathrm{M}$ IAA (iodoacetamide) for $45 \mathrm{~min}$ to $1 \mathrm{~h}$ at room temperature in the dark and then enzymatically digested by trypsin containing procaine. The tryptic digestion was performed at $37{ }^{\circ} \mathrm{C}$ for $18 \mathrm{~h}$ (overnight) and then terminated by acidification with $100 \%$ FA (formic acid) to $\mathrm{pH}$ range 2-3 [20]. The resulting peptides were analyzed by Ekspert NanoLC425 HPLC system (Eksigent, USA) for chromatographic separation. Peptides (with $2 \mu \mathrm{L}$ injection volume) from each sample were loaded onto trapping cartridge $(10 \times 0.5 \mathrm{~mm})$ packed with CHROMXP C18CL $5 \mu \mathrm{m}$ particles, washed using mobile phase A $(0.1 \%$ FA in DI-Water) at a flow rate of 10 $\mu \mathrm{L} / \mathrm{min}$ for $3 \mathrm{~min}$. Subsequently, peptides were fractionated on the analytical column $(150 \times 0.3 \mathrm{~mm})$ packed with CHROMXP $\mathrm{C} 18 \mathrm{CL}, 120 \mathrm{~A}^{\circ}, 3 \mu \mathrm{m}$ particles. The mobile phase $\mathrm{A}$ and $\mathrm{B}$ $(0.1 \%$ FA in acetonitrile) were run at a flow rate of $2 \mu \mathrm{l} / \mathrm{min}$ over $55 \mathrm{~min}$ to establish gradient elution that was $38 \mathrm{~min}$ $3-30 \%$ B; followed by $5 \min 30-40 \%$ B and $2 \min 40-80 \%$ B; maintained at $80 \% \mathrm{~B}$ for $3 \mathrm{~min}$ and finally equilibrated at $3 \%$ B.

Peptide fractions eluted from the HPLC system were directly injected into the mass spectrometer with nanospray ${ }^{\circledR}$ Ion Source. Data acquisition was set with a Triple $\mathrm{TOF}^{\mathrm{TM}} 5600^{+}$ system (AB SCIEX software), and the MS data were acquired in the positive ion mode, with a selected mass range of 400-1250 m/z. Smart IDA (Information Dependent Acquisition) was obtained through high-resolution TOF/MS survey scan followed by a product ion scan resulted from MS/MS analysis for the most abundant 40 ions whose threshold was over 150 counts, and charge ranged from +2 to +5 with cycle speed of $1.5 \mathrm{~s}$.

\subsubsection{Mass Spectrometric Data Analysis}

Data acquisition was performed with Analyst ${ }^{\circledR} \mathrm{TF}$ 1.7.1 (AB SCIEX software). MS raw data files from the Triple TOF $^{\text {TM }}$ $5600^{+}$system were converted into MGF (Mascot Generic Format) files, which were then analyzed by Peptide Shaker (v1.16.27) for protein identification. The databases used for searching $T$. cellulosilytica TB100 were Swiss-prot and TrEMBL database containing 3,587 proteins [21]. The X!Tandem Algorithm was used for peptide identification. The data search parameters were set up as follows: Trypsin digestion with a maximum of two missed cleavage sites was considered along with fixed modification of cysteines by carbamidomethylation. Acetylation of lysine residues, peptide $\mathrm{N}$ termini, deamidation of asparagine and glutamine residues; and methionine oxidation were set as variable modifications. The presence of signal peptide sequences was determined using the ProtParam database [22].

\subsubsection{Statistical Analysis}

All experiments were done in at least two independent replicates, and the presented data are the mean values of replicates \pm standard deviation using Microsoft Excel 2010 (Microsoft, USA). Differences between means were examined by one-way ANOVA (analysis of variance) followed by the Student's $t$ test using SPSS 22.0 software (SPSS Inc., Chicago, USA). The significance of differences was considered at a probability value less than 0.05 . 


\section{RESULTS}

\subsection{Microorganism and its Cellulolytic Activity}

The cellulase activity of $T$. cellulosilytica was confirmed by Congo red method. It produced a wide clear halo zone around the colonies due to the degradation of CMC (Fig. 1).
A.

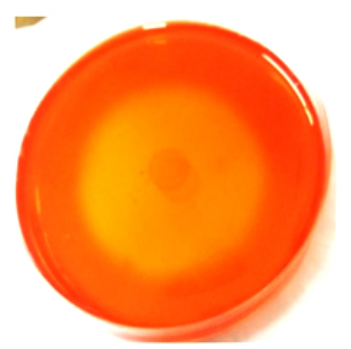

B.

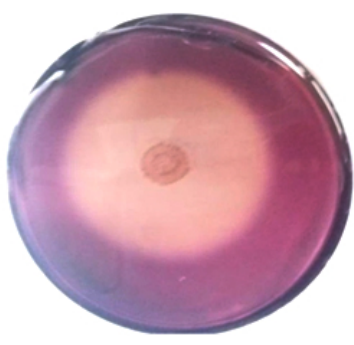

Fig. (1). Screening the cellulolytic activity of T. cellulosilytica using Congo red method. The microorganism was spotted in the center of the plate containing $\mathrm{CMC}$ agar media. A wide clearance zone formed around the colonies in the left picture after addition of Congo red. For good contrast, $1 \mathrm{M} \mathrm{HCl}$ was added after destaining step leading to the darkness of the color of Congo red in the right picture.

\subsection{Cellulolytic Activity Assay Using Different Carbon Sources}

The cellulolytic activity of T. cellulosilytica $\mathrm{TB} 100^{\mathrm{T}}$ was estimated upon its growth on either CMC or RS. The cellulase production was gradually increased till reaching its maximum activity that was estimated at $0.132 \pm 0.080 \mathrm{IU} / \mathrm{mL}$ and $0.298 \pm 0.161 \mathrm{IU} / \mathrm{mL}$ on the $8^{\text {th }}$ day and $7^{\text {th }}$ day of incubation for both CMC and RS substrates, respectively. Subsequently, the cellulolytic activity decreased with longer incubation (Fig. 2).

\subsection{Partial Characterization of Crude Extract}

The cellulolytic activity of the CFE was optimal at $\mathrm{pH} 4.5$ and 7.5 evaluated by 0.137 and $0.132 \mathrm{IU} / \mathrm{mL}$, respectively, (Fig. 3A). The optimum temperature of cellulase was $50^{\circ} \mathrm{C}$ with a maximum activity of $0.136 \mathrm{IU} / \mathrm{mL}$. Cellulase enzyme was able to tolerate temperature up to $70^{\circ} \mathrm{C}$ (Fig. 3B). The concentration of $0.75 \%$ of $\mathrm{CMC}$ was found to induce the highest amount of cellulase estimated by $0.132 \mathrm{IU} / \mathrm{mL}$ (Fig. 3C).

\subsection{Secretome Analysis}

The extracellular proteins of $T$. cellulosilytica $\mathrm{TB} 100^{\mathrm{T}}$, secreted in the presence of different substrates, were confidently identified by LC-MS/MS based proteomic analysis. After the enzymatic digestion of the secretome proteins by trypsin, a total of 9 peptides and 127 peptides were detected in the MS/MS spectra of CMC and RS, (Supplementary files 2 and 3 ). The resulted peptides were then searched against different databases giving 6 proteins and 31 proteins were produced in the $\mathrm{CMC}$ and RS, respectively, (Supplementary files 4 and 5).
The molecular weight and isoelectric point (PI) of all identified proteins were ranged from $15-106.3 \mathrm{kDa}$ and 3.52-6.43 as shown in Tables $\mathbf{1}$ and 2. Most produced proteins had an acidic $\mathrm{pH}$ and extracellularly secreted by the action of signal peptides.

The secretomic produced proteins were functionally categorized and pie charted according to their roles in the deconstruction of lignocellulosic biomass (Fig. 4). Regarding $\mathrm{CMC}$, the only secreted cellulolytic enzyme was glucanase (7\%). On the other hand, the proteins detected in the RS secretome were grouped as cellulases $(26 \%)$, hemicellulases $(16 \%)$, proteases $(10 \%)$, and other proteins $(48 \%)$ as shown in (Fig. 4). Out of 31 proteins, 9 proteins (8.43) belonged to glycoside hydrolases (GHs) which were classified into different families according to (Carbohydrate Active enZYmes) CAZY database (http://www.cazy.org) [23]. The GH families included were GH6 (2), GH9 (2), GH10 (2), GH43 (1), GH48 (1) and GH81 (1). In addition, ten enzymes were annotated as containing carbohydrate binding modules (CBMs).

\section{DISCUSSION}

Actinomycetes are considered as potential sources of bioactive secondary metabolites like antibiotics, enzymes and growth factors [12]. Cellulose active enzymes, "cellulases" are considered as important enzymes certainly produced from actinobacteria, including T. cellulosilytica $\mathrm{TB} 100^{\mathrm{T}}$. An additional thermophilic property of $T$. cellulosilytica $\mathrm{TB} 100^{\mathrm{T}}$ strain makes it a potential source for the production of thermostable cellulases, the cause of choice of the provided actinomycete strain in this study.

We confirmed the cellulolytic activity of T. cellulosilytica $\mathrm{TB} 100^{\mathrm{T}}$ by Congo red which is the most widely used method for preliminary screening of cellulolytic actinomycetes, bacteria and fungi [5]. Congo red binds strongly with $\beta-1,4-D$ glycoside linkage in polysaccharides, forming red complex [24]. This strong complex does not form except with polymers [25]. So, a large clear halo zone formed around colonies due to degradation of CMC polymer as a role of cellulase produced from $T$. cellulosilytica. Although the formation of a large clear zone on CMC agar plates, it doesn't imply good productivity in liquid media [17].

It is also worth noting that the maximum CMCase activity of a thermophilic actinomycete, Thermomonospora fusca BD25 which is the closest one to the strain of our study, was also weak and estimated at $0.05 \mathrm{IU} / \mathrm{mL}$, nearly half the CMCase activity from our strain of interest [26]. Similarly, lower weak cellulolytic activity was produced maximally from Geobacillus sp. DUSELR7 on day 7 and from Brevibacillus sp. DUSELG12 on day 10 as $0.058 \mathrm{IU} / \mathrm{mL}$ and $0.02 \mathrm{IU} / \mathrm{mL}$ respectively [27]. In another study, the cellulase activity of Bacillus subtilis AS3 was $0.07 \mathrm{IU} / \mathrm{mL}$ in basal control medium and increased 6 folds to be $0.43 \mathrm{IU} / \mathrm{mL}$ after cultivation in the optimized medium using Placket-Burman design [28]. 


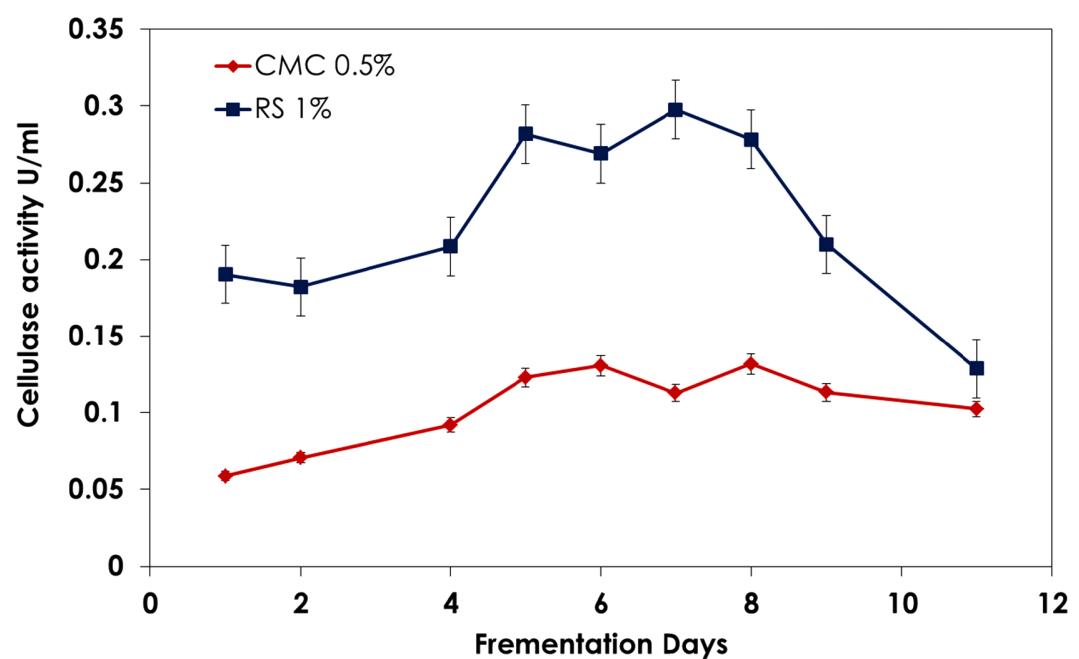

Fig. (2). Effect of incubation period/fermentation time on the cellulolytic activity of T. cellulosilytica using different carbon sources, CMC and RS. The symbols ( $\bullet$ with a red line representing $0.5 \% \mathrm{CMC}$ and $(\mathbf{\bullet})$ with blue line representing $1 \% \mathrm{RS}$.

A.

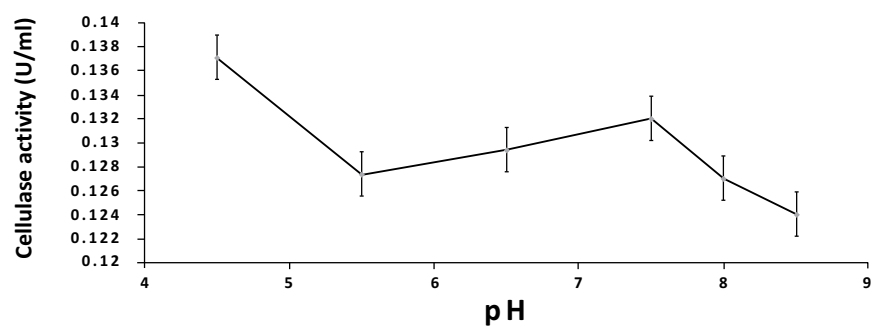

B.

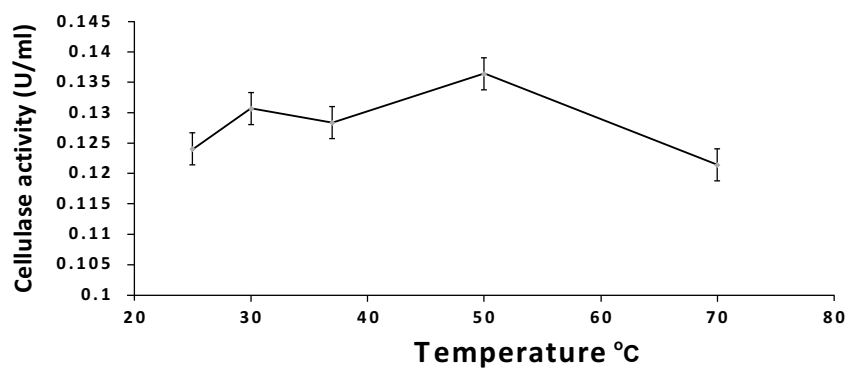

C.

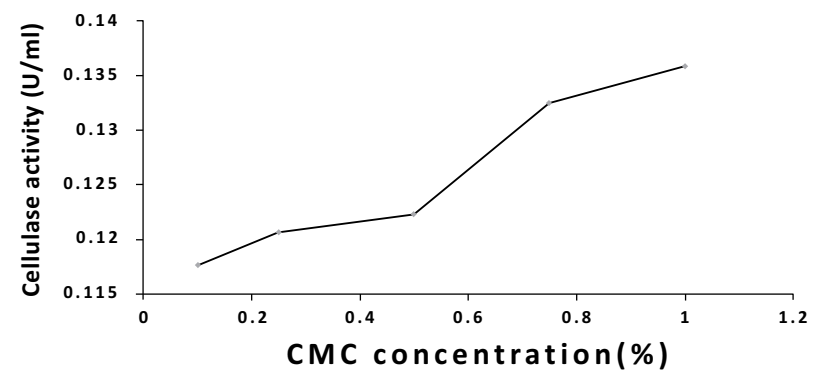

Fig. (3). Partial characterization of cellulase including:

A. Effect of different $\mathrm{pH}(\boldsymbol{\Lambda})$ on cellulase production.

B. Effect of different incubation temperatures $(\diamond)$ on cellulase production.

C. Effect of different CMC concentration ( $\mathbf{-}$ ) on cellulase production. 
A.

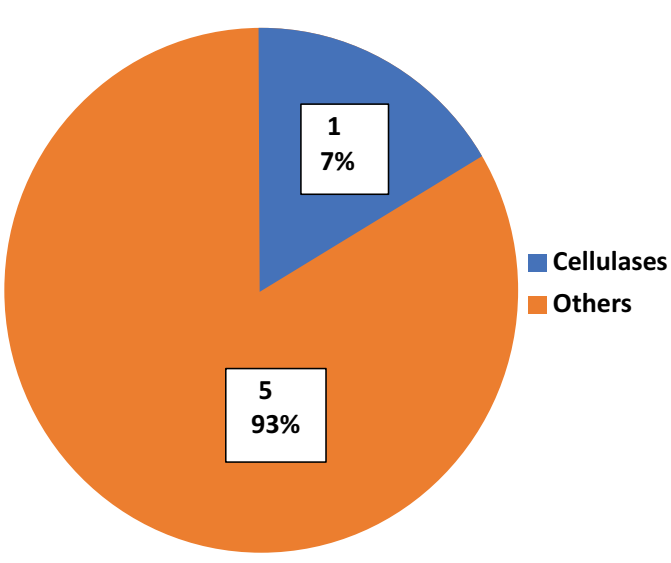

B.

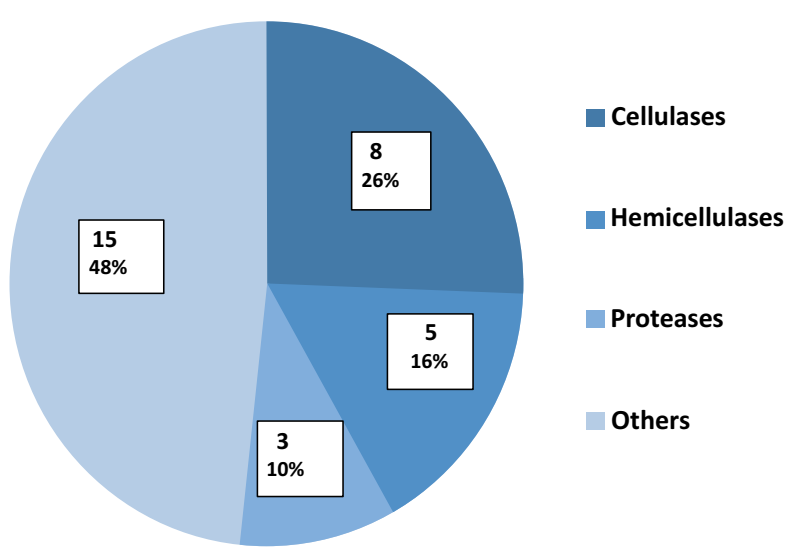

Fig. (4). Different classes of proteins identified in the T. cellulosilytica TB100 secretome using (A). CMC as a simple substrate and (B). rice straw as a complex substrate after analysis by LC-MS/MS data.

Table 1. Functional classification of proteins detected in the secretome of T. cellulosilytica TB100 using CMC as simple substrate.

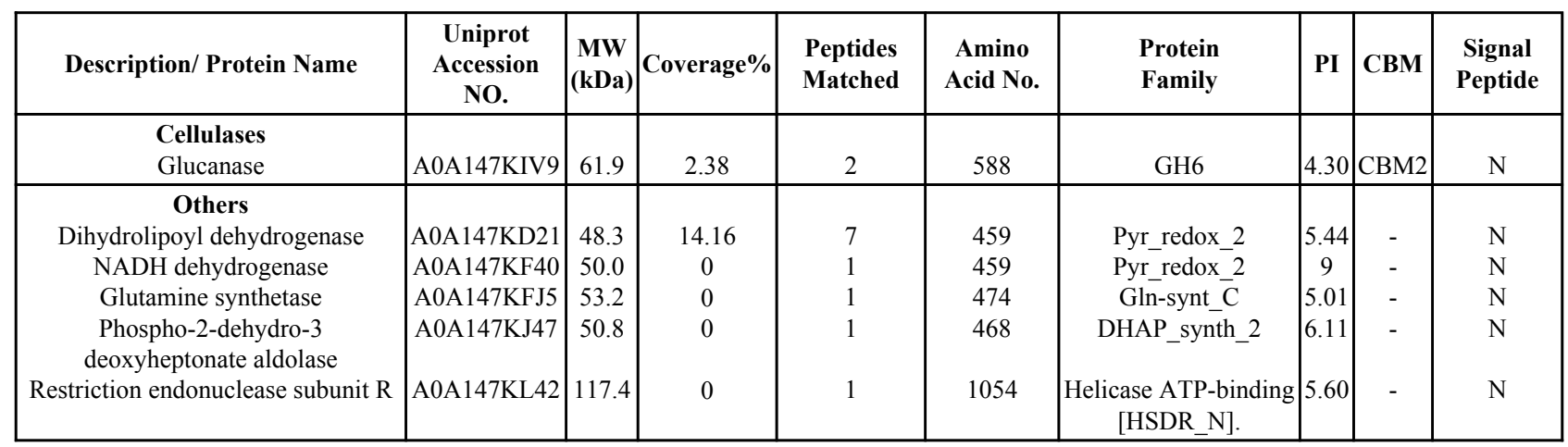

Table 2. Functional classification of proteins detected in the secretome of $T$. cellulosilytica TB100 using RS as complex substrate.

\begin{tabular}{|c|c|c|c|c|c|c|c|c|c|}
\hline Description/ Protein Name & $\begin{array}{c}\text { Uniprot } \\
\text { Accession } \\
\text { NO. }\end{array}$ & $\begin{array}{c}\text { MW } \\
\text { (kDa) }\end{array}$ & Coverage\% & $\begin{array}{l}\text { Peptides } \\
\text { Matched }\end{array}$ & $\begin{array}{c}\text { Amino } \\
\text { Acid No. }\end{array}$ & $\begin{array}{l}\text { Protein } \\
\text { Family }\end{array}$ & PI & CBM & $\begin{array}{l}\text { Signal } \\
\text { Peptide }\end{array}$ \\
\hline $\begin{array}{c}\text { Cellulases } \\
\text { Endoglucanase } \\
\text { Cellulose } 1,4 \text {-beta-cellobiosidase } \\
\text { Glucanase } \\
\text { Endoglucanase } \\
\text { Glycoside Glycoside hydrolase } \\
\text { Endoglucanase } \\
\text { Endoglucanase } \\
\text { Glucanase }\end{array}$ & $\begin{array}{l}\text { A0A147KLC2 } \\
\text { A0A147KIK5 } \\
\text { A0A147KI07 } \\
\text { A0A0A7A855 } \\
\text { A0A147KHU4 } \\
\text { A0A147KHF1 } \\
\text { A0A147KMV8 } \\
\text { A0A147KIV9 }\end{array}$ & $\begin{array}{c}68.3 \\
106.3 \\
46.6 \\
46.2 \\
100.8 \\
103.8 \\
102.4 \\
61.9\end{array}$ & $\begin{array}{c}5.02 \\
15.9 \\
17.4 \\
4.78 \\
1.59 \\
16.17 \\
17.45 \\
34.69\end{array}$ & $\begin{array}{c}2 \\
16 \\
11 \\
3 \\
1 \\
14 \\
15 \\
17\end{array}$ & $\begin{array}{l}618 \\
981 \\
454 \\
439 \\
941 \\
965 \\
957 \\
588\end{array}$ & $\begin{array}{c}\text { Cellulase } \\
\text { GH48 } \\
\text { GH6 } \\
\text { Cellulase } \\
\text { GH81 } \\
\text { GH9 } \\
\text { GH9 } \\
\text { GH6 }\end{array}$ & $\begin{array}{l}4.51 \\
4.35 \\
5.77 \\
4.71 \\
5.03 \\
4.67 \\
4.14 \\
4.30\end{array}$ & $\begin{array}{c}\text { CBM3 } \\
\text { CBM2 } \\
\text { CBM2 } \\
\text { CBM2 } \\
- \\
\text { CBM2,3 } \\
\text { CBM2 } \\
\text { CBM2 }\end{array}$ & $\begin{array}{l}\mathrm{Y} \\
\mathrm{Y} \\
\mathrm{N} \\
\mathrm{Y} \\
\mathrm{Y} \\
\mathrm{N} \\
\mathrm{N} \\
\mathrm{N}\end{array}$ \\
\hline $\begin{array}{c}\text { Hemicellulases } \\
\text { Beta-xylanase } \\
\text { Beta-xylanase } \\
\text { Xyloglucanase } \\
\text { Xylose isomerase } \\
\text { Beta-xylosidase }\end{array}$ & $\begin{array}{c}\text { A0A147KDP3 } \\
\text { A0A147KJ27 } \\
\text { A0A147KMS2 } \\
\text { A0A147KE49 } \\
\text { A0A147KMT4 }\end{array}$ & $\begin{array}{l}53.4 \\
50.5 \\
97.8 \\
43.1 \\
61.8\end{array}$ & $\begin{array}{l}11.02 \\
21.1 \\
2.29 \\
3.12 \\
2.18\end{array}$ & $\begin{array}{l}8 \\
8 \\
5 \\
1 \\
3\end{array}$ & $\begin{array}{l}490 \\
474 \\
919 \\
385 \\
550\end{array}$ & $\begin{array}{c}\text { GH10 } \\
\text { GH10 } \\
- \\
\text { AP_endonuc_2 } \\
\text { GH43 }\end{array}$ & $\begin{array}{l}5.41 \\
4.49 \\
4.29 \\
5.09 \\
5.88\end{array}$ & $\begin{array}{c}\text { CBM2 } \\
\text { CBM2 } \\
\text { CBM2 } \\
- \\
-\end{array}$ & $\begin{array}{l}\mathrm{Y} \\
\mathrm{Y} \\
\mathrm{Y} \\
\mathrm{N} \\
\mathrm{N}\end{array}$ \\
\hline
\end{tabular}




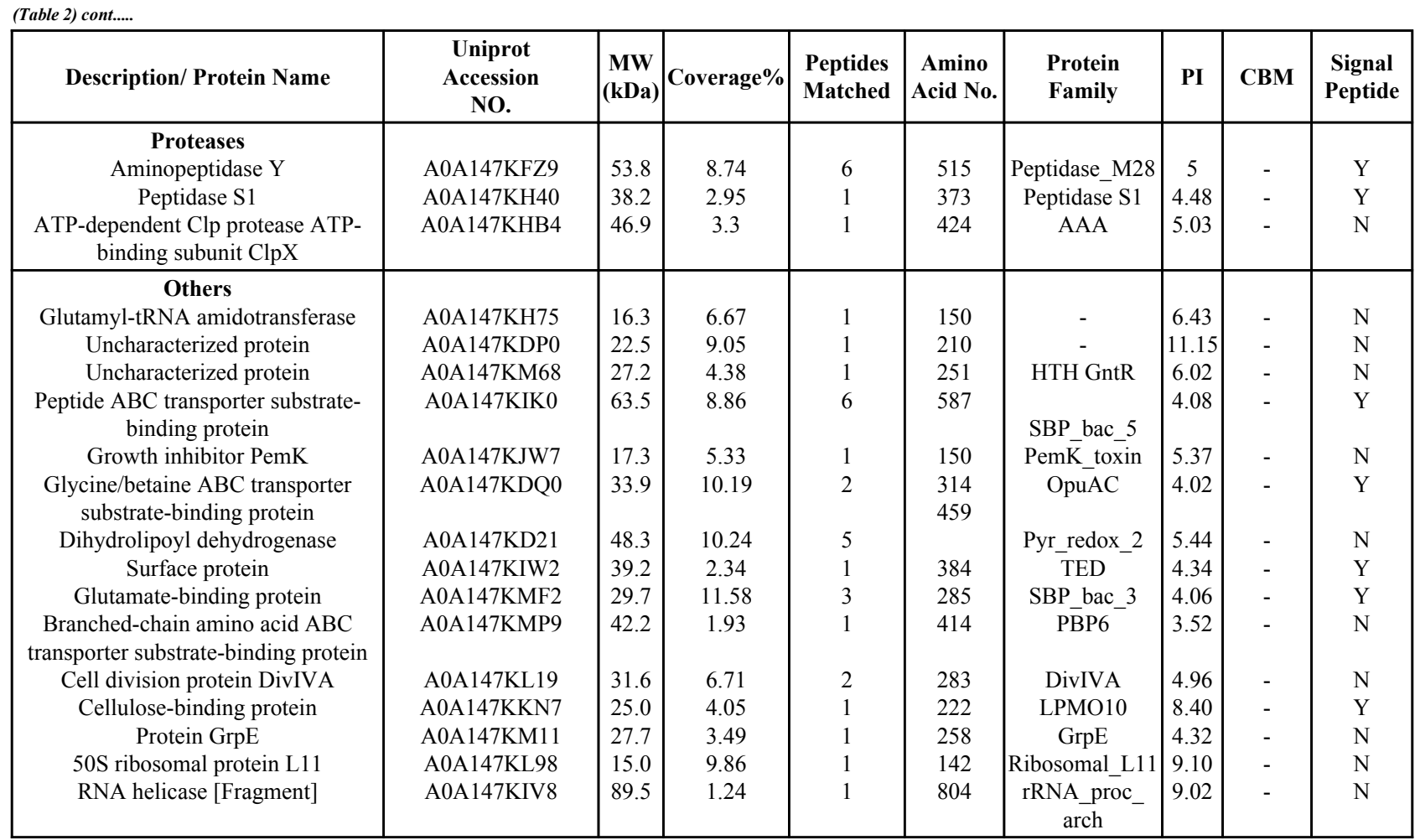

On the other hand, there are some actinobacterial strains in other studies that produced CM Case with moderate and high maximum activity including actinomycete BAY 21 with $1.381 \pm 0.024 \mathrm{IU} / \mathrm{mL}$ [7] and Streptomyces DSK59 with 20 $\mathrm{IU} / \mathrm{mL}$ [12]. Another alkalothermophilic actinomycete produced CM Case with the activity of $23 \mathrm{IU} / \mathrm{mL}, 8.5 \mathrm{IU} / \mathrm{mL}$ and $12.5 \mathrm{IU} / \mathrm{mL}$ when cellulose paper powder, wheat bran and corncob were used as the substrate, respectively [29].

Regarding the cellulase, it is produced gradually till reaching maximum activity followed by a decline with longer incubation. Longer incubation period enhances the production of proteases. Proteases degrade subsequent enzymes resulting in diminished cellulolytic activity [30]. Prasad reported (2013) other reasons related to feedback inhibition occurred by the accumulation of end products [31].

Unlike most researches interested in the isolation of cellulolytic strains, the first study directed toward secretomic analysis of T. cellulosilytica $\mathrm{TB} 100^{\mathrm{T}}$ was conducted [32]. The secretory protein profiles of $T$. cellulosilytica grown on different carbon sources, including CMC and RS, were compared. The proteomic study revealed a significant upregulation in the lignocellulolytic enzymes expression of in the case of RS than CMC.

Lignocellulases are inducible enzymes [20]. Their production is dependent on the type or nature of the substrate used the culture media, which is known as substrate-induced phenomena [33, 34]. Do Vale and his colleagues (2012) showed that the complexity of the substrate affected the variety of the produced enzymes [35]. The CMC secretome contained six secretory proteins involving only one cellulase (glucanase). This low expression level of cellulases produced in the CMC secretome has an advantage of better isolation, purification, and studying the kinetic parameters of this cellulase, leading to decrease production cost on the large industrial scale.

On the contrary, more lignocelluloses (31 proteins) were identified in the RS secretome. The different classes of proteins produced were cellulases, hemicellulases, proteases, and other proteins. These varieties of enzymes were produced in the RS secretome due to its complex composition of cellulose (41\%), hemicellulose (20\%) tightly packed with lignin (12\%) [36].

The lignin content of RS hinders the accessibility of the hydrolytic enzymes to their substrates [20]. Therefore, thermal and chemical pretreatment of RS is an essential process to make their cellulosic content more accessible to cellulases [37]. However, RS pretreatment is two-sided coin having drawbacks, including the formation of inhibitory products such as phenolics, aliphatic acids, and furan derivatives making feedback inhibition on the hydrolytic enzymes and further the fermentation process [38].

Most of the produced proteins contain carbohydratebinding modules (CBMs) previously known as cellulose then carbohydrate binding domains (CBDs). CBMs are noncatalytic domains covalently bonded to the hydrolytic enzymes of different GH families. Like GHs, CBMs were classified into families ranged from family1 to 49 according to amino acid sequence similarities [39]. CBMs are responsible for proteinpolysaccharide recognition [40]. They can target (hemi) cellulases to their carbohydrate polymers by increasing their concentrations at the substrates sites. Then, they change the carbohydrate structure, promoting their degradation by the effect of the hydrolytic enzymes [39, 41]. So, CBMs have a positive effect on increasing the rate and yield of the lignocellulolytic enzymes.

The absence of BGLs was noticed in the secretome of $T$. cellulosilytica grown on the corresponding substrates. This result was assured by quantitative assay for BGLs activity 
using pNPG (para nitro phenyl beta- D-glucopyranoside) as a substrate showing its negligible activity (data not shown). Our similar result was reported by other researches referring to the cause of the intracellular formation of this enzyme [42]. So, commercial cellulase preparations should be amended with BGLs from other sources, especially fungal ones, which are the highest BGL producers for efficient lignocellulolytic biomass hydrolysis [43].

The production, activity, and stability of actinomycetes' cellulases are greatly affected by $\mathrm{pH}$ and temperature [44]. Thermophilic cellulase system showed stability and activity at a wide $\mathrm{pH}$ range from 4.5-8.5 with a slight non-significant increase at $\mathrm{pH} 4.5$ and $7.5(\mathrm{p}<0.05)$. Other researches showed similar results in which the optimum $\mathrm{pH}$ range of cellulases was generally reported from 4.2-5.2 [45]. However, Prasad and co-workers (2013) assured that maximum cellulase activity from Streptomyces griseorubens (Accession No. AB184139) was at pH 7 [31]. The activity of CM Case from Bacillus sp. SMIA-2 was found to be optimum at $\mathrm{pH} 8$ [46]. The main reason may be attributed to the complex cellulase system required for complete cellulose degradation. This complex system is composed of 3 different enzymes acting synergistically [47]. Each enzyme has its optimum $\mathrm{pH}$ that ensures proper working.

Cellulase isolated from $T$. cellulosilytica showed the maximum activity at $50^{\circ} \mathrm{C}$ with $94 \%$ of retained activity at $70^{\circ} \mathrm{C}$. Other researchers showed similar results from Streptomyces lividans66, Bacillus sp., MSL2 strain, Bacillus sp DUSELR13, and Geobacillus sp WSUCF1 [48, 49]. This higher temperature reaction leads to faster reaction rates and better degradation of cellulosic materials [46]. The maximum cellulolytic activity achieved at $0.75 \%$ concentration of CMC. Higher concentrations were too viscous that hindered the cellulolytic assay.

\section{CONCLUSION}

T. cellulosilytic a is a promising source of thermostable cellulases that are active over a wide range of $\mathrm{pH}$ and temperature. Also, LC-MS/MS based proteomic analysis revealed that $T$. cellulosilytic a has variable cellulases that are efficient for the degradation of simple/complex lignocellulosic materials. T. cellulosilytic a is an interesting actinomycete for more studies in the production of thermostable cellulases for successful applications, such as biofuel production.

\section{ETHICS APPROVAL AND CONSENT TO PARTI- CIPATE}

Not applicable.

\section{HUMAN AND ANIMAL RIGHTS}

No animals/humans were used for studies that are the basis of this research.

\section{CONSENT FOR PUBLICATION}

Not applicable.

\section{AVAILABILITY OF DATA AND MATERIALS}

Not applicable.

\section{FUNDING}

None.

\section{CONFLICT OF INTEREST}

The authors declare no conflict of interest, financial or otherwise.

\section{ACKNOWLEDGEMENTS}

The authors are thankful for the proteomics unit in the children's cancer hospital, especially Dr. Sameh Magdeldin, Dr. Hassan Shikshaky, and Dr. Aya Osama for the proteomic analysis. We would like to thank Dr. Haitham Saeed for supporting this study.

\section{SUPPLEMENTARY MATERIAL}

Supplementary material is available on the publisher's web site along with the published article.

Supplementary file 1: Pellets of T. cellulosilytica grown on $0.5 \%$ CMC and $1 \%$ RS after 2 days and 7 days of incubation.

Supplementary file 2: Peptides identified in the CMC secretome by LC-MS/MS technique.

Supplementary file 3: Proteins identified in the CMC secretome by LC-MS/MS technique.

Supplementary file 4: Peptides identified in the RS secretome by LC-MS/MS technique.

Supplementary file 5: Proteins identified in the RS secretome by LC-MS/MS technique.

\section{REFERENCES}

[1] Horn SJ, Vaaje-Kolstad G, Westereng B, Eijsink VG. Novel enzymes for the degradation of cellulose. Biotechnol Biofuels 2012; 5(1): 45. [http://dx.doi.org/10.1186/1754-6834-5-45] [PMID: 22747961]

[2] Sukumaran RK, Singhania RR, Pandey A. Microbial cellulasesproduction, applications and challenges. JSIR 2005; 64: 832-44.

[3] Agbor VB, Cicek N, Sparling R, Berlin A, Levin DB. Biomass pretreatment: Fundamentals toward application. Biotechnol Adv 2011; 29(6): 675-85.

[http://dx.doi.org/10.1016/j.biotechadv.2011.05.005] [PMID: 21624451]

[4] Juturu V, Wu JC. Microbial cellulases: Engineering, production and applications. Renew Sust Energ Rev 2014; 33: 188-203. [http://dx.doi.org/10.1016/j.rser.2014.01.077]

[5] Yang W, Meng F, Peng J, et al. Isolation and identification of a cellulolytic bacterium from the Tibetan pig's intestine and investigation of its cellulase production. Electron J Biotechnol 2014; 17: 262-7.

[http://dx.doi.org/10.1016/j.ejbt.2014.08.002]

[6] Bayer EA, Shoham Y, Lamed R. Cellulose-decomposing bacteria and their enzyme systems The prokaryotes. New York: Springer 2006; pp. 578-617.

[7] Mohanta YK. Isolation of cellulose-degrading actinomycetes and evaluation of their cellulolytic potential. Bioeng Biosci 2014; 2: 1-5.

[8] Kulcu R, Yaldiz O. Determination of aeration rate and kinetics of composting some agricultural wastes. Bioresour Technol 2004; 93(1): 49-57.

[http://dx.doi.org/10.1016/j.biortech.2003.10.007] [PMID: 14987720]

[9] Hendriks AT, Zeeman G. Pretreatments to enhance the digestibility of lignocellulosic biomass. Bioresour Technol 2009; 100(1): 10-8. [http://dx.doi.org/10.1016/j.biortech.2008.05.027] [PMID: 18599291] 
[10] Lekshmi M, Jayadev A, Navami S. Isolation and screening of actinomycetes from marine samples for enzyme production. Int J Sci Eng Res 2014; 5: 199-204.

[11] Trigo C, Ball A. Production of extracellular enzymes during the solubilisation of straw by Thermomonospora fusca BD25. Appl Microbiol Biotechnol 1994; 41: 366-72.

[http://dx.doi.org/10.1007/BF00221233]

[12] Budihal SR, Agsar D, Patil SR. Enhanced production and application of acidothermophilic Streptomyces cellulase. Bioresour Technol 2016; 200: 706-12.

[http://dx.doi.org/10.1016/j.biortech.2015.10.098] [PMID: 26556405]

[13] Kukolya J, Nagy I, Láday M, et al. Thermobifida cellulolytica sp. nov., a novel lignocellulose-decomposing actinomycete. Int J Syst Evol Microbiol 2002; 52(Pt 4): 1193-9.

[PMID: 12148627]

[14] Kawai F, Kawabata T, Oda M. Current knowledge on enzymatic PET degradation and its possible application to waste stream management and other fields. Appl Microbiol Biotechnol 2019; 103(11): 4253-68. [http://dx.doi.org/10.1007/s00253-019-09717-y] [PMID: 30957199]

[15] Obeng EM, Adam SNN, Budiman C, Ongkudon CM, Maas R, Jose J. Lignocellulases: A review of emerging and developing enzymes, systems, and practices. Bioresour Bioprocess 2017; 4: 1-22. [http://dx.doi.org/10.1186/s40643-017-0146-8]

[16] Kukolya J, Dobolyi C, Hornok L. Isolation and identification of thermophilic cellulolytic actinomycetes. Acta Phytopathol Entomol Hung 1997; 32: 97-107.

[17] Teather RM, Wood PJ. Use of Congo red-polysaccharide interactions in enumeration and characterization of cellulolytic bacteria from the bovine rumen. Appl Environ Microbiol 1982; 43(4): 777-80. [http://dx.doi.org/10.1128/AEM.43.4.777-780.1982] [PMID: 7081984]

[18] Taniguchi M, Tanaka M, Matsuno R, et al. Evaluation of chemical pretreatment for enzymatic solubilization of rice straw. Eur J Appl Microbiol Biotechnol 1982; 14: 35-9. [http://dx.doi.org/10.1007/BF00508001]

[19] Miller GL. Use of dinitrosalicylic acid reagent for determination of reducing sugar. Anal Chem 1959; 31: 426-8.

[http://dx.doi.org/10.1021/ac60147a030]

[20] Adav SS, Cheow ESH, Ravindran A, Dutta B, Sze SK. Label free quantitative proteomic analysis of secretome by Thermobifida fusca on different lignocellulosic biomass. J Proteomics 2012; 75(12): 3694-706.

[http://dx.doi.org/10.1016/j.jprot.2012.04.031] [PMID: 22575269]

[21] Bairoch A, Apweiler R. The SWISS-PROT protein sequence database and its supplement TrEMBL in 2000. Nucleic Acids Res 2000; 28(1): $45-8$.

[http://dx.doi.org/10.1093/nar/28.1.45] [PMID: 10592178]

[22] Walker JM. The proteomics protocols handbook. Humana Press 2005; p. 969.

[http://dx.doi.org/10.1385/1592598900]

[23] Lombard V, Golaconda Ramulu H, Drula E, Coutinho PM, Henrissat B. The carbohydrate-active enzymes database (CAZy) in 2013. Nucleic Acids Res 2014; 42: D490-5.

[http://dx.doi.org/10.1093/nar/gkt1178] [PMID: 24270786]

[24] Santhi VS, Gupta A, Saranya S, Jebakumar SRD. A novel marine bacterium Isoptericola sp. JS-C42 with the ability to saccharifying the plant biomasses for the aid in cellulosic ethanol production. Biotechnol Rep (Amst) 2014; 1-2: 8-14.

[http://dx.doi.org/10.1016/j.btre.2014.05.002] [PMID: 28435797]

[25] Wood PJ, Erfle JD, Teather RM. Use of complex formation between Congo Red and polysaccharides in detection and assay of polysaccharide hydrolases. Methods Enzymol 1988; 160: 59-74. [http://dx.doi.org/10.1016/0076-6879(88)60107-8]

[26] Tuncer Mr, Ball AS, Rob A, et al. Optimization of extracellular lignocellulolytic enzyme production by a thermophilic actinomycete Thermomonospora fusca BD25. Enzyme Microb Technol 1999; 25: 38-47.

[http://dx.doi.org/10.1016/S0141-0229(99)00012-5]

[27] Rastogi G, Muppidi GL, Gurram RN, et al. Isolation and characterization of cellulose-degrading bacteria from the deep subsurface of the Homestake gold mine, Lead, South Dakota, USA. J Ind Microbiol Biotechnol 2009; 36(4): 585-98. [http://dx.doi.org/10.1007/s10295-009-0528-9] [PMID: 19189143]

[28] Deka D, Bhargavi P, Sharma A, Goyal D, Jawed M, Goyal A. Enhancement of cellulase activity from a new strain of Bacillus subtilis by medium optimization and analysis with various cellulosic substrates. Enzyme Res 2011; 2011151656 [http://dx.doi.org/10.4061/2011/151656] [PMID: 21637325]
[29] George SP, Ahmad A, Rao MB. Studies on carboxymethyl cellulase produced by an alkalothermophilic actinomycete. Bioresour Technol 2001; 77(2): 171-5

[http://dx.doi.org/10.1016/S0960-8524(00)00150-4] [PMID: 11272024]

[30] Singh S, Moholkar VS, Goyal A. Isolation, identification, and characterization of a cellulolytic Bacillus amyloliquefaciens strain SS35 from rhinoceros dung. ISRN Microbiol 2013; 2013728134 [http://dx.doi.org/10.1155/2013/728134] [PMID: 23762763]

[31] Prasad P, Singh T, Bedi S. Characterization of the cellulolytic enzyme produced by Streptomyces griseorubens [Accession No. AB184139] isolated from Indian soil. J King Saud University Sci 2013; 25: 245-50.

[http://dx.doi.org/10.1016/j.jksus.2013.03.003]

[32] Liu D, Li J, Zhao S, et al. Secretome diversity and quantitative analysis of cellulolytic Aspergillus fumigatus $\mathrm{Z} 5$ in the presence of different carbon sources. Biotechnol Biofuels 2013; 6(1): 149. [http://dx.doi.org/10.1186/1754-6834-6-149] [PMID: 24131596]

[33] Juhasz T, Szengyel Z, Reczey K, et al. Characterization of cellulases and hemicellulases produced by Trichodermareesei on various carbon sources. Process Biochem 2005; 40: 3519-25. [http://dx.doi.org/10.1016/j.procbio.2005.03.057]

[34] Manavalan A, Adav SS, Sze SK. iTRAQ-based quantitative secretome analysis of Phanerochaete chrysosporium. J Proteomics 2011; 75(2): 642-54.

[http://dx.doi.org/10.1016/j.jprot.2011.09.001] [PMID: 21945728]

[35] Do Vale LH, Gómez-Mendoza DP, Kim MS, et al. Secretome analysis of the fungus Trichoderma harzianum grown on cellulose. Proteomics 2012; 12(17): 2716-28

[http://dx.doi.org/10.1002/pmic.201200063] [PMID: 22745025]

[36] Narra M, Dixit G, Divecha J, Madamwar D, Shah AR. Production of cellulases by solid state fermentation with Aspergillus terreus and enzymatic hydrolysis of mild alkali-treated rice straw. Bioresour Technol 2012; 121: 355-61.

[http://dx.doi.org/10.1016/j.biortech.2012.05.140] [PMID: 22864171]

[37] Binod P, Sindhu R, Singhania RR, et al. Bioethanol production from rice straw: An overview. Bioresour Technol 2010; 101(13): 4767-74. [http://dx.doi.org/10.1016/j.biortech.2009.10.079] [PMID: 19944601]

[38] Chandel AK, Singh OV. Weedy lignocellulosic feedstock and microbial metabolic engineering: Advancing the generation of 'Biofuel'. Appl Microbiol Biotechnol 2011; 89(5): 1289-303. [http://dx.doi.org/10.1007/s00253-010-3057-6] [PMID: 21181146]

[39] Moser F, Irwin D, Chen S, Wilson DB. Regulation and characterization of Thermobifida fusca carbohydrate-binding module proteins E7 and E8. Biotechnol Bioeng 2008; 100(6): 1066-77. [http://dx.doi.org/10.1002/bit.21856] [PMID: 18553392]

[40] Boraston AB, Bolam DN, Gilbert HJ, Davies GJ. Carbohydratebinding modules: Fine-tuning polysaccharide recognition. Biochem J 2004; 382(Pt 3): 769-81.

[http://dx.doi.org/10.1042/BJ20040892] [PMID: 15214846]

[41] Shoseyov O, Shani Z, Levy I. Carbohydrate binding modules: biochemical properties and novel applications. Microbiol Mol Biol Rev 2006; 70(2): 283-95

[http://dx.doi.org/10.1128/MMBR.00028-05] [PMID: 16760304]

[42] Singh S, Tiwari R, Renuse S, Pranaw K, Nain L. Proteomic analysis of Streptomyces sp. ssr-198 grown on paddy straw. J Basic Microbiol 2015; 55(6): 790-7.

[http://dx.doi.org/10.1002/jobm.201400639] [PMID: 25639595]

[43] Singhania RR, Patel AK, Sukumaran RK, Larroche C, Pandey A. Role and significance of beta-glucosidases in the hydrolysis of cellulose for bioethanol production. Bioresour Technol 2013; 127: 500-7. [http://dx.doi.org/10.1016/j.biortech.2012.09.012] [PMID: 23069613]

[44] McCarthy A. Lignocellulose-degrading actinomycetes. FEMS Microbiol Lett 1987; 46: 145-63.

[http://dx.doi.org/10.1111/j.1574-6968.1987.tb02456.x]

[45] Zinchenko G. Optimization of enzymatic hydrolysis of fibre sludge from pulp mill. Central Ostrobothnia University of Applied Sciences 2012.

46] Ladeira SA, Cruz E, Delatorre AB, et al. Cellulase production by thermophilic Bacillus sp: SMIA-2 and its detergent compatibility. Electron J Biotechnol 2015; 18: 110-5.

[http://dx.doi.org/10.1016/j.ejbt.2014.12.008]

[47] Lynd LR, Weimer PJ, van Zyl WH, Pretorius IS. Microbial cellulose utilization: Fundamentals and biotechnology. Microbiol Mol Biol Rev 2002; 66(3): 506-77.

[http://dx.doi.org/10.1128/MMBR.66.3.506-577.2002] [PMID: 12209002] 
[48] Théberge M, Lacaze P, Shareck F, Morosoli R, Kluepfel D. Purification and characterization of an endoglucanase from Streptomyces lividans 66 and DNA sequence of the gene. Appl Environ Microbiol 1992; 58(3): 815-20

[http://dx.doi.org/10.1128/AEM.58.3.815-820.1992] [PMID: 1575483]
[49] Sriariyanun M, Tantayotai P, Yasurin P, et al. Production, purification and characterization of an ionic liquid tolerant cellulase from Bacillus sp. isolated from rice paddy field soil. Electron J Biotechnol 2016; 19: 23-8.

[http://dx.doi.org/10.1016/j.ejbt.2015.11.002]

(C) 2020 Elmahdy et al.

This is an open access article distributed under the terms of the Creative Commons Attribution 4.0 International Public License (CC-BY 4.0), a copy of which is available at: (https://creativecommons.org/licenses/by/4.0/legalcode). This license permits unrestricted use, distribution, and reproduction in any medium, provided the original author and source are credited. 